\title{
Treatments used in menopausal women susceptible to dyslipidemia and diabetes
}

\author{
VELOSO, A. G. B. ${ }^{1}$, GAMA, E. F. ${ }^{2}$ and MAIFRINO, L. B. M. ${ }^{1,3}$ \\ ${ }^{1}$ Laboratório de Estudos Morfoquantitativo e Imunohistoquímico, Universidade São Judas Tadeu - USJT, \\ Rua Taquari, 546, Mooca, CEP 03166-000, São Paulo, SP, Brazil \\ ${ }^{2}$ Laboratório de Percepção Corporal e Movimento, Universidade São Judas Tadeu - USJT, Rua Taquari, 546, \\ Mooca, CEP 03166-000, São Paulo, SP, Brazil \\ ${ }^{3}$ Instituto Dante Pazzanese de Cardiologia, Av. Dr. Dante Pazzanese, 500, Vila Mariana, CEP 04012-909, \\ São Paulo, SP, Brazil \\ *E-mail: lmaifrino@uol.com.br
}

\begin{abstract}
Objective: The objective of this study was to investigate the efficacy of types of treatment most used in menopausal women with dyslipidemia and susceptible to insulin resistance. Material and Methods: In the period between 2006 and 2016, articles of the PubMed database were evaluated using the keywords: pancreas, menopause, dyslipidemia and treatment. The following parameters were evaluated: title, year of publication, author, country of origin, studied model (human or animal), types of analysis (biometric, biochemical, physiological, morphological and immunohistochemical). Results: Of 530 articles investigated, 11 were evaluated, among which $45 \%$ used physical exercise as a treatment, $37 \%$ used the pharmacological treatment and $18 \%$ used diet. As for the year and country where the study was performed, $73 \%$ of the articles were published in the last six years (2011-2016), and 73\% were published in the United States. In $27.3 \%$ of the articles were used animal models, and $72.7 \%$ used human models. The most employed analysis in the studies was the biochemical, and the least used $(5 \%)$ was the morphological. Conclusion: Although physical exercise was the most common treatment in this study, the other treatments (diet and drugs) are of paramount importance to prevent pancreatic diseases and the development of type 2 diabetes, which certainly trigger a clinical picture of dyslipidemia, resulting in the irreversible deterioration of pancreatic cells.
\end{abstract}

Keywords: pancreas, dyslipidemia and diabetes, physical exercise, treatment.

\section{Introduction}

Aging is a natural process of individuals development that occurs gradually. It involves biological, functional, structural, chemical, environmental and sociocultural factors, such as quality of life, diet, sedentary and physical activity, which are closely linked to the healthy or pathological aging. Biological factors such as functional decline of cells promote continuous imbalance of hormonal regulatory systems that produce metabolic and physiological changes, leading to reduction of functional reserves and making the elderly more prone to diseases (INSTITUTO..., 2010; SALLIS, 2000).

According to estimates of the World Health Organization (ORGANIZAÇÃO..., 2013) in 2020 we will have a greater number of older people in relation to children aged under five years. In 2060, 25\% of the population will be over 65 years, of which $55 \%$ will be women.

Policies of prevention and treatment are indispensable tools because aging is characterized by a functional decline resulting from decreased aerobic capacity and progressive weakness of body muscles that are accentuated from the age of 50 , the period coinciding with the menopause that greatly affects the elderly's quality of life (AL-NUAIM, MIRDAD, AL-RUBEAAN et al., 1997; AKAHOSHI, SODA, NAKASHIMA et al., 2001; GRAFF-IVERSEN, THELLE and HAMMAR, 2008).

Menopause is characterized by inactivity of ovaries and consequent deprivation of estrogen. It represents the beginning of a new phase of women's lives around the age of 45-55 years. In addition, there is a trend to body mass gain, and women are susceptible to changes in lipid metabolism, increasing the levels of total cholesterol, lipoproteins and triglycerides, and reduction of HDL-cholesterol levels, leading to a highly favorable to atherogenesis lipid profile, especially when associated with diabetes and hypertension (GRAFF-IVERSEN, THELLE and HAMMAR, 2008; STACHOWIAK, PERTYNSKI and PERTYNSKA-MARCZEWSKA, 2015).

It is known that cholesterol is a precursor in the formation of female sex hormones. Thus, with deprivation of estrogen, there is an increase of remnant cholesterol, consequently increasing low-density lipoproteins (LDL), very low-density lipoproteins (VLDL) and triglycerides (TG), resulting in a highly favorable to atherogenesis lipid profile. Excess fatty acids in circulation contribute to the accumulation of these lipids in the adipose and muscle tissue, promoting weight gain in the body, liver and pancreas (GRAFF-IVERSEN, THELLE and HAMMAR, 2008; FARIA, CORREIA-JUNIOR, ANJO et al., 2013; STACHOWIAK, PERTYNSKI and PERTYNSKA-MARCZEWSKA, 2015; PANDEY, CHAWLA and GUCHHAIT, 2015).

Pancreas is an essential organ to maintain energetic homeostasis, and in a clinical picture of dyslipidemia, it produces insulin (hypoglycemic) and glucagon (hyperglycemic) with 
the function of balancing the blood sugar concentration. In cases of excess lipids in the blood, the pancreas tries to balance the hyperglycemia by increasing the insulin production ( $\beta$-cells). The chronic state leads to exhaustion that impairs the function of $\beta$-cells and develops a pre-diabetes condition. Excess cholesterol leads to lipotoxicity in pancreatic $\beta$-cells, causing apoptosis, and leading to decreased insulin production (LIU and MAUVAIS-JARVIS, 2010). Such clinical picture associated with estrogen deficiency can be a determining factor in changing the pre- and postmenopausal profile (WU, FANG, ZHENG et al., 2013)

Dyslipidemia is a factor of risk and disease in cases of pancreatic dysfunction, therefore, the first line of action must include its prevention for premenopausal and postmenopausal women looking for different types of treatment. Studies have pointed that physically active individuals enjoy a better quality of life and have lower mortality rates, resulting in greater longevity (MATSUDO and MATSUDO, 1992; ANTUNES, SANTOS, CASSILHAS et al., 2006)

It is extremely important to know how to prevent the physiological and endocrine changes caused by deprivation of ovarian hormones in menopausal women to encourage their aging with quality of life and well-being.

Thus, the aim of this study is to identify the types of treatments used in menopausal women predisposed to dyslipidemia and diabetes.

\section{Methods}

The search was performed in the PubMed electronic database because this is a complete source that includes the journals of Medline, Pre-Medline and Health STAR. The following descriptors were used randomly: "pancreas" and "dyslipidemia" and "exercise" and "menopause" and "treatment" (Table 2). Only articles published in the last 10 years, from 2006 to 2016 were surveyed. The aim was to analyze the methods of treatment used in menopausal women with dyslipidemia.

The initial analysis included the surveyed titles. Then, the articles were separated per proximity of the proposed theme. The abstracts were read, ensuring that the articles chosen for reading in full met the following inclusion criteria: studied model (animal or human), type of treatment, analyzed parameters (biometric, biochemist, physiological, immunological and morphological), year and country of publication of the articles. The following were excluded: review articles, book chapters, dissertations, theses, conference proceedings and government reports.

The articles were selected according to the established criteria to show the treatment used in the pancreatic diseases in menopausal women with dyslipidemia.

\section{Results}

Analyzing the selected articles, it appears that different types of treatment are prescribed to the elderly, such as hormone replacement, dietary supplements, diet, drugs and physical exercise, to reach benefits and reverse processes of dyslipidemia, pointing to reduced LDL levels, thus preventing the development of diabetes and improving quality of life (ALMEIDA, PITANGA, FREITAS et al., 2012; KITABCHI, MCDANIEL, WAN et al., 2013; OMIYA, MINAMI, SATO et al., 2015; AMARAL, LIMA, ORNELAS et al., 2015).

In total, 530 articles were found, and 11 articles were selected for further analysis (Tables 1 and 2).

Regarding the year and the country where the study was performed, $73 \%$ of the articles were published in the last six years (2011-2016), and the United States is leader in number of publications, with eight articles (73\%), followed by England with two publications (18\%), and Netherlands with one publication $(9 \%)$ (Table 2$)$.

All selected articles used human or animal models in menopause, with dyslipidemia and relating the pancreas as the target organ. Of the 11 articles, $27.3 \%$ used animal models and $72.7 \%$ used human models. Note that $36.4 \%$ of the studies used menopausal women and $18.2 \%$ used ovariectomized rats.

Analyzing the studies in humans, we found that in $50 \%$ of the articles were used biochemical, biometric, physiological and immune parameters for analysis and in the other $50 \%$ were used biochemical, biometric and physiological parameters. In the animal model, we found that $33 \%$ used only biochemical and immunological parameters, while $67 \%$ analyzed the biochemical, biometric, physiological, immunological and morphological parameters. Despite this, the biochemical analysis was the most used in the total number of articles, and the least used was the morphological with only $5 \%$ (Figure 1 ).

The most used types of treatments in menopausal women with dyslipidemia were physical exercise (45.4\%), diet (18.2\%) and pharmacological $(36.4 \%)$. In relation to articles using physical exercise, in $60 \%$ was employed aerobic exercise, in $40 \%$ was used combined exercise (aerobic and anaerobic), and in $18.2 \%$ was used diet (Figure 2).

The Table 3 shows the types of treatments and the principals results found in the articles studied.

\section{Discussion}

Most of selected articles were published in American journals (73\%). The article by Malin, Solomon, Blaszczak et al. (2013) stands out because it shows an epidemic of obese people, about 79 million pre-diabetic individuals, and the urgency

Table 1. Number of total articles by descriptor and per exclusion criteria. Period of 2006-2016.

\begin{tabular}{lllllcc}
\hline & & & Key words & Articles & Selected \\
\hline Pancreas & Exercise & Menopause & Dyslipidemia & Treatment & 0 & 0 \\
Pancreas & Exercise & Menopause & Dyslipidemia & & 0 & 0 \\
Pancreas & Exercise & Menopause & & & 0 & 0 \\
Pancreas & & Menopause & & & 29 & 1 \\
Pancreas & & & Dyslipidemia & Treatment & $\mathbf{1 8 7}$ & $\mathbf{2}$ \\
Pancreas & Exercise & & Dyslipidemia & Treatment & 4 & 3 \\
Pancreas & Exercise & & & & 310 & 5 \\
\hline
\end{tabular}


of taking measures given the estimate of development of type 2 diabetes by $30 \%$ of this population. The second country with largest number of publications was England (18\%), and the articles had reports of the difficulty faced with reducing the rate of pre-diabetic people (MALIN and KIRWAN, 2012).

With menopause, there is decline of estrogen levels and is established metabolic imbalance, which leads to weight increase, consequently increasing lipids in the circulation of blood vessels (dyslipidemia), resulting in oxidative stress and insulin resistance (IR). Studies on these changes are quite significant in order to ensure improved quality of life because women live a third of their lives in pre- and postmenopausal phases.

Based on this information, we will discuss the main treatments used by menopausal women prone to dyslipidemia and predisposed to diabetes.

\subsection{Diet treatment}

Menopausal women in search of a better quality of life see the diet as an alternative for reducing the symptoms caused by the effects of menopause.

Table 2. General index of selected articles mentioning the author's name, year of publication, Authors' country and Country of publication.

\begin{tabular}{|c|c|c|c|c|c|c|c|}
\hline Title & Author & Year & $\begin{array}{l}\text { Authors' } \\
\text { country }\end{array}$ & $\begin{array}{l}\text { Country of } \\
\text { publication }\end{array}$ & Model & Treatment & $\begin{array}{c}\text { Analyzed } \\
\text { parameters }\end{array}$ \\
\hline $\begin{array}{l}\text { Impaired } \beta \text {-cell function } \\
\text { attenuates training effects } \\
\text { by reducing the increase } \\
\text { in heart rate reserve in } \\
\text { patients with myocardial } \\
\text { infarction. }\end{array}$ & $\begin{array}{l}\text { Omiya, } \\
\text { Minami, } \\
\text { Sato et al. }\end{array}$ & 2015 & Japan & Holland & Human & Exercise & $\begin{array}{l}\text { Biometric, } \\
\text { biochemical, } \\
\text { physiological, } \\
\text { immunological }\end{array}$ \\
\hline
\end{tabular}

\section{$17 \beta$-estradiol} protects against glucosamine-induced pancreatic $\beta$-cell dysfunction.

DHEA supplementation

in ovariectomized rats reduces impaired glucose-stimulated insulin secretion induced by a high-fat diet.

Adverse association between obesity and menopause in mice treated with bezafibrate, a pan peroxisome proliferator-activated receptor agonist.

$\begin{array}{lll}\text { Kang, Chen, } 2014 \quad \text { Japan } & \begin{array}{l}\text { United } \\ \text { States of }\end{array}\end{array}$
America

Animal Pharmacological

Biochemical, immunological Wu et

\section{Biometric,} biochemical, physiological, immunological and morphological

Almeida, 2014 South England Animal Pharmacological Nachbar et al. Africa
Biometric, biochemical, physiological,
Faria, CorreiaJunior, Anjo et al.
United 2013 Brazil States of America
Animal Pharmacological immunological and morphological

Pancreatic $\beta$-cell function increases in a linear dose-response manner following exercise training in adults with prediabetes.

Pancreatic $\beta$-cell function is a stronger predictor of changes in glycemic control after an aerobic exercise intervention than

Solomon, United

Malin, 2013 France States of Human Exercise Karstoft et al.
United

Malin, Blaszczak et al.

tates of

United America America

Human Exercise

Biometric, biochemical, physiological

insulin sensitivity.

Effects of high-protein versus high-carbohydrate diets on markers of $\beta$-cell function, oxidative stress, lipid peroxidation, proinflammatory cytokines, and adipokines in obese, premenopausal women without diabetes: a randomized controlled trial.

\begin{tabular}{|c|c|c|c|c|c|c|}
\hline $\begin{array}{l}\text { Kitabchi, } \\
\text { Mcdaniel, } \\
\text { Wan et al. }\end{array}$ & 2013 & $\begin{array}{l}\text { United } \\
\text { States of } \\
\text { America }\end{array}$ & $\begin{array}{l}\text { United } \\
\text { States of } \\
\text { America }\end{array}$ & Human & Diet & $\begin{array}{c}\text { Biometric, } \\
\text { biochemical, } \\
\text { physiological }\end{array}$ \\
\hline
\end{tabular}

Biometric, biochemical, physiological 
Table 2. Continued...

\begin{tabular}{|c|c|c|c|c|c|c|c|}
\hline Title & Author & Year & $\begin{array}{l}\text { Authors' } \\
\text { country }\end{array}$ & $\begin{array}{l}\text { Country of } \\
\text { publication }\end{array}$ & Model & Treatment & $\begin{array}{c}\text { Analyzed } \\
\text { parameters }\end{array}$ \\
\hline $\begin{array}{l}\text { Fasting hyperglycaemia } \\
\text { blunts the reversal } \\
\text { of impaired glucose } \\
\text { tolerance after exercise } \\
\text { training in obese older } \\
\text { adults. }\end{array}$ & $\begin{array}{l}\text { Malin and } \\
\text { Kirwan }\end{array}$ & 2012 & $\begin{array}{l}\text { United } \\
\text { States of } \\
\text { America }\end{array}$ & England & Human & Exercise & $\begin{array}{l}\text { Biometric, } \\
\text { biochemical, } \\
\text { physiological, } \\
\text { immunological }\end{array}$ \\
\hline $\begin{array}{l}\text { Effects of soy protein and } \\
\text { isoflavones on glycemic } \\
\text { control and insulin } \\
\text { sensitivity: a 6-mo double- } \\
\text { blind, randomized, } \\
\text { placebo-controlled trial in } \\
\text { postmenopausal Chinese } \\
\text { women with prediabetes } \\
\text { or untreated early } \\
\text { diabetes. }\end{array}$ & $\begin{array}{l}\text { Liu and } \\
\text { Mauvais- } \\
\text { Jarvis }\end{array}$ & 2010 & China & $\begin{array}{l}\text { United } \\
\text { States of } \\
\text { America }\end{array}$ & Human & Diet & $\begin{array}{l}\text { Biometric, } \\
\text { biochemical, } \\
\text { physiological, } \\
\text { immunological }\end{array}$ \\
\hline $\begin{array}{l}\text { Effects of exercise } \\
\text { training intensity on } \\
\text { pancreatic beta-cell } \\
\text { function. }\end{array}$ & $\begin{array}{c}\text { Slentz, } \\
\text { Tanner, } \\
\text { Bateman et al. }\end{array}$ & 2009 & $\begin{array}{l}\text { United } \\
\text { States of } \\
\text { America }\end{array}$ & $\begin{array}{l}\text { United } \\
\text { States of } \\
\text { America }\end{array}$ & Human & Exercise & $\begin{array}{l}\text { Biometric, } \\
\text { biochemical, } \\
\text { physiological, } \\
\text { immunological }\end{array}$ \\
\hline $\begin{array}{l}\text { Effects of raloxifene } \\
\text { on insulin sensitivity, } \\
\text { beta-cell function, } \\
\text { and hepatic insulin } \\
\text { extraction in normal } \\
\text { postmenopausal women }\end{array}$ & $\begin{array}{l}\text { Nagamani, } \\
\text { Szymajda, } \\
\text { Sepilian et al. }\end{array}$ & 2008 & $\begin{array}{l}\text { United } \\
\text { States of } \\
\text { America }\end{array}$ & $\begin{array}{l}\text { United } \\
\text { States of } \\
\text { America }\end{array}$ & Human & Pharmacological & $\begin{array}{l}\text { Biometric, } \\
\text { biochemical, } \\
\text { immunological }\end{array}$ \\
\hline
\end{tabular}

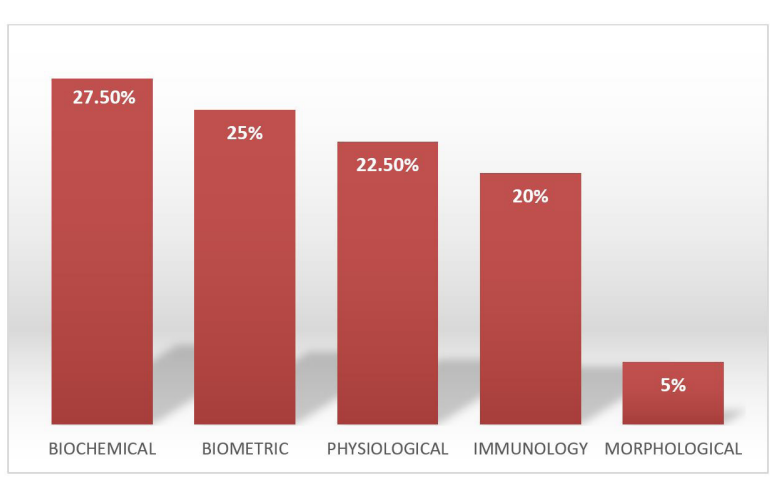

Figure 1. Percentage of biochemical, biometric and physiological parameters analyzed in the selected articles.

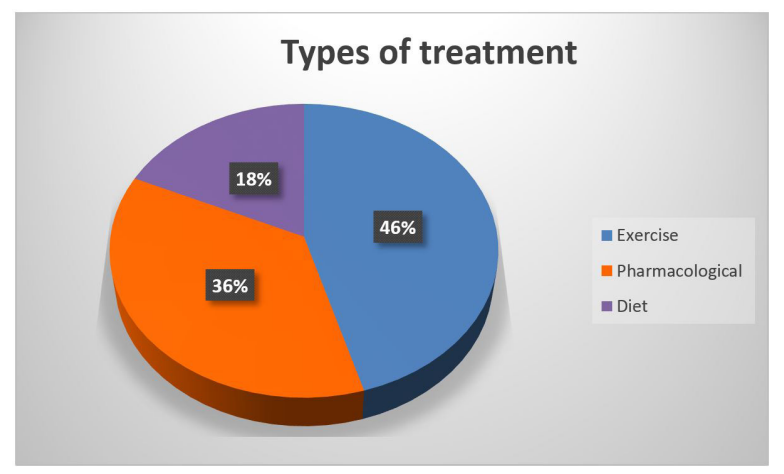

Figure 2. Types of treatment: Diet, Pharmacological and Physical exercise.
Analyzing articles related to diet (Table 2), we found that $50 \%$ of these articles were of premenopausal obese women using different types of diets. With this approach, Kitabchi, Mcdaniel, Wan et al. (2013) has compared diets rich in carbohydrate (HC) and protein (HP). It found that HP diets promoted decrease in inflammation, oxidative stress, lipid peroxidation, and inflammatory cytokines, and improved functions of $\beta$-cells and insulin sensitivity, preventing cardiovascular diseases, compared to a high carbohydrate diet (HC). On the other hand, Liu and Mauvais-Jarvis (2010), has compared diets containing soy protein and isoflavones, and concluded that the values related to insulin sensitivity and glycemic control were similar. However, it was observed that the soybean group (soy protein with isoflavones) obtained a reduction in 2 hours and 6 hours post-glucose load tests (PG-2h-6h). Given the results found, further studies on the subject are key because the presented diets are nutritionally similar.

\subsection{Pharmacological treatment}

Of the 11 selected articles, 36\% used pharmacological intervention, of which $100 \%$ were human model studies, $83.3 \%$ used biochemical, biometric and physiological analysis, and 16.7\% used immunohistochemical analysis, as shown in Table 2.

Note that $75 \%$ of the articles mention the benefits of drug therapy while preserving the pancreatic islets and decreasing insulin resistance (NAGAMANI, SZYMAJDA, SEPILIAN et al., 2008; VERAS, ALMEIDA, NACHBAR et al., 2014), reducing lipid levels (triglycerides and cholesterol), and consequently lowering insulin levels (FARIA, CORREIA-JUNIOR, 
ANJOS et al., 2013). However, Kang, Chen, Wu et al. (2014) emphasizes the side effects of some drugs that possibly induce resistance to insulin, apoptosis of $\beta$-cells, thereby developing type 2 diabetes.
Continuous use drugs occasionally may have their therapeutic effects decreased, requiring periodic adjustment of the dose to achieve an effective result. However, when combining continuous use drugs with regular exercise practice, the quality of life is

Table 3. General index of selected articles mentioning the chosen treatment and the results.

\begin{tabular}{|c|c|}
\hline Exercise treatment & Results \\
\hline $\begin{array}{c}\text { Combination } \\
\text { (Aerobic and Anaerobic) }\end{array}$ & $\begin{array}{c}\text { Improved the } \beta \text {-cells function; } \\
\text { Improved VO2; } \\
\uparrow \text { High density lipoproteins (HDL); } \\
\downarrow \text { Low density lipoproteins (LDL); } \\
\uparrow \text { Insulin sensitivity; } \\
\downarrow \text { Insulin secretion; } \\
\downarrow \text { Weight; } \\
\downarrow \text { TG. } \\
\uparrow \text { Function of } \beta \text {-cells; } \\
\uparrow \text { VO2max; } \\
\uparrow \text { Cardiovascular fitness; } \\
\uparrow \text { Insulin sensitivity; } \\
\downarrow \text { Fasting glucose }\end{array}$ \\
\hline Aerobic & $\begin{array}{c}\downarrow \text { Insulin secretion; } \\
\downarrow \text { Visceral adipose tissue; } \\
\downarrow \text { Triglycerides; } \\
\downarrow \text { Weight; } \\
\downarrow \text { BMI; } \\
\downarrow \text { Compensatory insulin secretion; } \\
\downarrow \text { Insulin secretion; } \\
\downarrow \text { GSIS }\end{array}$ \\
\hline Pharmacological treatment & Results \\
\hline Glucosamine (Osteoarthritis) & $\begin{array}{c}\downarrow \text { Insulin secretion; } \\
\downarrow \text { Influx of Ca2+; } \\
\downarrow \text { Insulin mRNA expression. } \\
\uparrow \text { Apoptosis of } \beta \text { cells; } \\
\uparrow \text { Size of the islets; } \\
\uparrow \text { ER stress-related protein. }\end{array}$ \\
\hline Dehydroepiandrosterone (DHEA) & $\begin{array}{c}\downarrow \text { Insuline secretion } \\
\downarrow \text { IR (insulin resistance); } \\
\uparrow \text { Estrogen; } \\
\uparrow \text { AKT (kinase protein); } \\
\uparrow \text { I.S. (insulin sensitivity). }\end{array}$ \\
\hline Bezafibrate (lipid-lowering) & $\begin{array}{c}\downarrow \downarrow \text { Body mass; } \\
\downarrow \text { Insulin levels; } \\
\downarrow \text { Hypertrophy of the islets; } \\
\downarrow \text { Diameter of the islets; } \\
\downarrow \text { Mass of the islets; } \\
\downarrow \text { HOMA-IR. (insulin resistance); } \\
\uparrow \text { Fasting glucose. }\end{array}$ \\
\hline Raloxifene & $\begin{array}{c}\downarrow \downarrow \text { Cholesterol; } \\
\downarrow \text { Low density lipoproteins (LDL); } \\
\downarrow \text { Hepatic extraction of insulin. }\end{array}$ \\
\hline
\end{tabular}


Table 3. Continued...

\begin{tabular}{|c|c|}
\hline Exercise treatment & Results \\
\hline Diet & Results \\
\hline \multirow{6}{*}{$\begin{array}{l}\text { Hypocaloric protein }(\mathrm{HP}) \text { and } \\
\text { Hypocaloric carbohydrate }(\mathrm{HC})\end{array}$} & HP diet (proteins): \\
\hline & $\uparrow I . S .($ insulin sensitivity); \\
\hline & 个Function of $\beta$-cells; \\
\hline & $\downarrow$ Oxidative stress; \\
\hline & $\downarrow$ Inflammatory markers; \\
\hline & $\downarrow$ Cardiovascular risk factors. \\
\hline
\end{tabular}

Soybeans:

Soybeans and Isoflavone

Improved insulin secretion induced

by postload glucose

improved by reducing the need for periodic adjustments as majority indication of physicians of all specialties.

\subsection{Physical exercise treatment}

Of the 11 articles analyzed (Table 2), 45\% used physical exercises as intervention method, and $100 \%$ of such interventions were performed in humans, divided in $60 \%$ using aerobic exercises and $40 \%$ using the combination of aerobic and anaerobic exercises.

All articles not only confirm, but also emphasize the beneficial effects of exercise as a non-pharmacological treatment for the improvement of lipid profile and weight loss, thus reversing the clinical picture of dyslipidemia, preventing pancreatic function by the decreased biosynthesis and secretion of insulin, normalization of the function of $\beta$-cells, thus avoiding a possible condition of type 2 diabetes. Consensus among many authors is that aerobic exercise in mild or moderate intensity was more effective in preserving the pancreas, preventing its function from exhaustion and leading to reversal of the clinical picture of dyslipidemia (SLENTZ, TANNER, BATEMAN et al., 2009; KANG, CHEN, WU et al., 2014).

\section{Conclusion}

Analyzing the selected articles, it's clear that physical exercise alone or combined with other treatments is the most used in menopausal women with dyslipidemia and susceptible to insulin resistance, because this type of intervention does not favor side effects. Diet is widely used as a first line of prevention, but needs further study. We highlight the association of drug treatment with regular physical exercise practice to favor the reduction of drug dosages or even polypharmacy. It is consensus that the use of multiple drugs may increase the risk of adverse side effects.

There are few studies observing morphoquantitative changes in different cells of the pancreatic islets. Many of the articles analyzed the relationship of treatments with biochemical changes (levels of triglycerides, LDL, HDL, HOMA IR, HOMA\% $\beta$-cell, OGTT), biometrical changes (weight, BMI) and physiological changes (blood pressure, $\mathrm{VO}_{2}$ ), but studies linking these changes to morphological changes in the cells that form the pancreatic islets are scarce.

The main conclusion of this study is that all kinds of treatments used in menopausal women with dyslipidemia, no matter if diet, drugs or physical exercise, are crucial for the prevention of pancreatic diseases, preventing the development of type 2 diabetes and the progression of dyslipidemia.

\section{Conflict of interest}

The author(s) declare(s) that there is no conflict of interest regarding the publication of this paper.

\section{References}

AKAHOSHI, M., SODA, M., NAKASHIMA, E., TSURUTA, M., ICHIMARU, S., SETO, S. and YANO, K. Effects of age at menopause on serum cholesterol, body mass index, and blood pressure. Atherosclerosis, 2001, vol. 156, n. 1, p. 157-163. PMid:11369009. http://dx.doi.org/10.1016/S0021-9150(00)00609-2.

ALMEIDA, BLA., PITANGA, FJG., FREITAS, MM., PITANGA, CPS., DANTAS, EHM. and BECK, CC. Caloric expenditure of different domains of physical activity as predictors of the absence of diabetes in adults. Revista Brasileira de Medicina do Esporte, 2012, vol. 18, n. 1, p. 17-21. http://dx.doi.org/10.1590/S1517-86922012000100003.

AL-NUAIM, AR., MIRDAD, S., AL-RUBEAAN, K., AL-MAZROU, Y., AL-ATTAS, O., AL-DAGHARI, N. and KHOJA, T. Populationbased epidemiological study on characteristics of risk factors of hypercholesterolemia in Saudi Arabia. International Journal of Cardiology, 1997, vol. 62, n. 1, p. 47-54. PMid:9363502. http:// dx.doi.org/10.1016/S0167-5273(97)00164-2.

AMARAL, F., LIMA, ANE., ORNELAS, E., SIMARDI, L., FONSECA, AFL. and MAIFRINO, MLB. Effect of different exercise intensities on the pancreas of animals with metabolic syndrome. Diabetes, Metabolic Syndrome and Obesity, 2015, vol. 8, p. 115-120. PMid:25709484.

ANTUNES, HKM, SANTOS, RF., CASSILHAS, R., SANTOS, RVT., BUENO, OFA. and MELLO, MT. Exercício físico e função cognitiva: uma revisão. Revista Brasileira de Medicina do Esporte, 2006, vol. 12, n. 2, p. 109-114.

FARIA, TS., CORREIA-JUNIOR, AL., ANJOS, TL., AGUILA, MB. and MANDARIM-DE-LACERDA, CA. Adverse association between obesity and menopause in mice treated with bezafibrate, a pan peroxisome proliferator-activated receptor agonist. Menopause, 2013, vol. 20, n. 12, p. 1264-1274. PMid:23632658. http://dx.doi. org/10.1097/GME.0b013e31828f5e3c.

GRAFF-IVERSEN, S., THELLE, DS. and HAMMAR, N. Serum lipids, blood pressure and body weight around the age of the menopause. European Journal of Cardiovascular Prevention and Rehabilitation, 2008, vol. 15, n. 1, p. 83-88. PMid:18277191. http://dx.doi. org/10.1097/HJR.0b013e3282f0e357. 
INSTITUTO BRASILEIRO DE GEOGRAFIA E ESTATÍSTICA - IBGE. Censo Demográfico 2010: características da população e dos domicilios resultados do universo. Brasília: IBGE, 2010.

KANG, L., CHEN, CH., WU, MH., CHANG, JK., CHANG, FM. and CHENG, JT. $17 \beta$-Estradiol protects against glucosamineinduced pancreatic $\beta$-cell dysfunction. Menopause, 2014, vol. 21, n. 11, p. 1239-1248. PMid:24714625. http://dx.doi.org/10.1097/ GME.0000000000000232.

KITABCHI, AE., MCDANIEL, KA., WAN, JY., TYLAVSKY, FA., JACOVINO, CA., SANDS, CW., NYENWE, EA. and STENTZ, FB. Effects of high-protein versus high-carbohydrate diets on markers of $\beta$-cell function, oxidative stress, lipid peroxidation, pro inflammatory cytokines, and adipokines in obese, premenopausal women without diabetes a randomized controlled trial. Diabetes Care, 2013, vol. 36, n. 7, p. 1919-1925. PMid:23404297. http://dx.doi.org/10.2337/ dc12-1912.

LIU, S. and MAUVAIS-JARVIS, F. Minireview: estrogenic protection of $\beta$-cell failure in metabolic diseases. Endocrinology, 2010, vol. 151, n. 3, p. 859-864. PMid:19966178. http://dx.doi.org/10.1210/ en.2009-1107.

MALIN, SK. and KIRWAN, JP. Fasting hyperglycaemia blunts the reversal of impaired glucose tolerance after exercise training in obese older adults. Diabetes, Obesity o Metabolism, 2012, vol. 14, n. 9, p. 835-841. PMid:22510250. http://dx.doi.org/10.1111/j.14631326.2012.01608.x.

MALIN, SK., SOLOMON, TP., BLASZCZAK, A., FINNEGAN, S., FILION, J. and KIRWAN, JP. Pancreatic $\beta$-cell function increases in a linear dose-response manner following exercise training in adults with prediabetes. American Journal of Physiology, Endocrinology and Metabolism, 2013, vol. 305, n. 10, p. E1248-E1254.

MATSUDO, SM. and MATSUDO, VKR. Prescrição e benefícios da atividade física na 3 idade. Revista Brasileira Ciência \& Movimento, 1992, vol. 5, n. 4, p. 19-30.

NAGAMANI, M., SZYMAJDA, A., SEPILIAN, V., URBAN, RJ. and GILKISON, C. Effects of raloxifene on insulin sensitivity, $\beta$-cell function, and hepatic insulin extraction in normal postmenopausal women. Fertility and Sterility, 2008, vol. 89, n. 3, p. 614-619. PMid:17586504. http://dx.doi.org/10.1016/j.fertnstert.2007.03.083.

OMIYA, K., MINAMI, K., SATO, Y., TAKAI, M., TAKAHASHI, E., HAYASHI, A., YAMAUCHI, M., SUZUKI, K., AKASHI, YJ., OSADA, N., IZAWA, KP. and WATANABE, S. Impaired $\beta$-cell function attenuates training effects by reducing the increase in heart rate reserve in patients with myocardial infarction. Journal of Cardiology, 2015, vol. 65, n. 2, p. 128-133. PMid:24953246. http://dx.doi. org/10.1016/j.jjcc.2014.04.012
ORGANIZAÇÃO MUNDIAL DE SAÚDE - OMS. O mundo terá 2 bilhões de idosos em 2050. 2013. Available from: <http://nacoesunidas. org/mundo-tera-2-bilhoes-de-idosos-em-2050-oms-diz-que-envelhecerbem-deve-ser-prioridade -global>. Access in: 12 Nov. 2015.

PANDEY, A., CHAWLA, S. and GUCHHAIT, P. Type 2 diabetes: Current understanding and future perspectives. IUBMB Life, 2015, vol. 67, n. 7, p. 506-513. PMid:26177573. http://dx.doi. org/10.1002/iub.1396.

SALLIS, JF. Age-related decline in physical activity: a synthesis of human and animal studies. Medicine and Science in Sports and Exercise, 2000, vol. 32, n. 9, p. 1598-1600. PMid:10994911. http://dx.doi. org/10.1097/00005768-200009000-00012.

SLENTZ, CA., TANNER, CJ., BATEMAN, LA., DURHEIM, MT., HUFFMAN, KM., HOUMARD, JA. and KRAUS, WE. Effects of exercise training intensity on pancreatic $\beta$-cell function. Diabetes Care, 2009, vol. 32, n. 10, p. 1807-1811. PMid:19592624. http://dx.doi. org/10.2337/dc09-0032.

SOLOMON, TPJ., MALIN, SK., KARSTOFT, K., KASHYAP, SR., HAUS, JM. and KIRWAN, JP. Pancreatic $\beta$-cell function is a stronger predictor of changes in glycemic control after an aerobic exercise intervention than insulin sensitivity. The Journal of Clinical Endocrinology and Metabolism, 2013, vol. 98, n. 10, p. 4176-4186. PMid:23966244. http://dx.doi.org/10.1210/jc.2013-2232.

STACHOWIAK, G., PERTYNSKI, T. and PERTYNSKA-MARCZEWSKA, M. Metabolic disorders in menopause. Przeglad Menopauzalny, 2015, vol. 14, n. 1, p. 59-64. PMid:26327890. http://dx.doi.org/10.5114/ pm.2015.50000.

VERAS, K., ALMEIDA, FN., NACHBAR, RT., JESUS, DS., CAMPOREZ, JP., CARPINELLI, AR., GOEDECKE, JH. and CARVALHO, CRO. DHEA supplementation in ovariectomized rats reduces impaired glucose-stimulated insulin secretion induced by a high-fat diet. FEBS Open Bio, 2014, vol. 4, n. 1, p. 141-146. PMid:24490138. http://dx.doi.org/10.1016/j.fob.2014.01.005.

WU, YJ., FANG, ZH., ZHENG, SG., WU, YB., WANG, Z. and LU, MA. Effect of danzhijiangtang capsule combined exercise on the protein expression of NADPH oxidase phosphox in pancreatic tissues of diabetic rats. Chinese Journal of Integrated Traditional And Western medicine, 2013, vol. 33, n. 5, p. 641-645. PMid:23905384.

Received March 15, 2017 Accepted August 1, 2017 